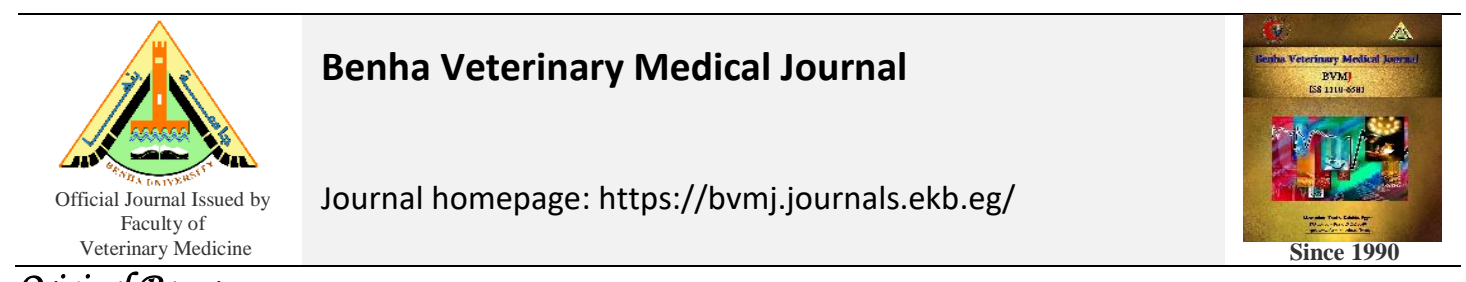

Original Paper

\title{
Pathological Studies on lung affections in sheep and goat at Qalyuobia Governorate
}

El-Mashad, Abdel-Baset Ismail, Moustafa, Shawky Ahmad, Amin, Aziza, Samy, Eman Mohamed Pathology Department, Faculty of Veterinary Medicine, Benha University, Egypt

\begin{tabular}{|c|c|}
\hline ARTICLE INFO & ABSTRACT \\
\hline Keywords & The gross and histopathological changes in the lungs of small ruminants at Qalyuobia \\
\hline Pathological & $\begin{array}{l}\text { Governorate were investigated. A total of } 159 \text { lung samples ( } 134 \text { sheep and } 25 \text { goats) showed } \\
\text { gross lesions were collected from February } 2018 \text { till November } 2019 \text {. Bacterial strains were }\end{array}$ \\
\hline lung affections & isolated from 26 cases out of $159(16.35 \%)$ including various types where Staphylococcus \\
\hline sheep & $\begin{array}{l}\text { aureus was the most predominant isolated strain from the lungs. Based on histopathological } \\
\text { examination, different types of pneumonia }(28.9 \%) \text { including; suppurative pneumonia }\end{array}$ \\
\hline goats & $\begin{array}{l}(10.69 \%) \text {, fibrinous pneumonia }(7.54 \%) \text {, interstitial pneumonia }(6.28 \%) \text {, granulomatous } \\
\text { pneumonia }(1.26 \%) \text { and verminous pneumonia }(3.14 \%) \text { were detected. Bronchitis and }\end{array}$ \\
\hline Received 03/03/2020 & bronchiolitis $(21.38 \%)$, and pleural fibrosis $(4.4 \%)$ were recorded. Pulmonary adenomatosis \\
\hline Accepted 22/03/2020 & and fibrosarcoma were detected in lungs of sheep with an incidence of $2.52 \%$ and $1.26 \%$, \\
\hline Available On-Line & respectively. This study concluded that pneumonia is an important lesion in the lungs of small \\
\hline $18 / 07 / 2020$ & $\begin{array}{l}\text { ruminant, and suppurative pneumonia was the most predominant type. Verminous pneumonia } \\
\text { was detected only in goats and not detected in sheep. Pulmonary adenomatosis were recorded } \\
\text { in lungs of sheep but not observed in goat. }\end{array}$ \\
\hline
\end{tabular}

\section{INTRODUCTION}

Respiratory diseases cause high mortality rate and economic losses in small ruminants due to the reduction of productivity, treatment costs, vaccination programs, and organ condemnations in abattoirs (Goodwin et al., 2004; Lacasta et al., 2008). The pathogenesis of the respiratory diseases is multifactorial, and mostly due to the interaction of many infectious agents, host defense, environmental factors, and stress. These predisposing factors decrease the local resistance of the respiratory mucosa and allow the growth of infectious agents in the respiratory tract lead to the development of different types of pneumonia (Yesuf et al., 2012).

Pneumonia is an inflammatory response of the lung tissue that develops when a certain threshold dose of infective agents is increased coupled with increased host susceptibility and decreased lung defense mechanisms. (Bruere et al., 2002).

The present work aimed to describe the gross and histopathological changes and identify the various bacterial agents in ovine and caprine lung lesions.

\section{MATERIAL AND METHODS}

\subsection{Sample collection}

A total of 159 lung samples (134 sheep and 25 goats) showed gross lesions were collected from both slaughtered and dead animals at Qalyuobia Governorate from February 2018 to November 2019.

\subsection{Bacterial isolation}

Lung samples were aseptically collected and placed in a sterile plastic bags in an ice box and were submitted to Bacteriology Department, Animal Health Research Institute, Tanta. The outer surface of the pneumonic lungs were first seared with a heated spatula before the cut inner surface of the lungs were inoculated into the nutrient broth and incubated at $37{ }^{\circ} \mathrm{C}$ for 24 hours and then sub-cultured into the following media; $5 \%$ sheep blood agar, Mannitol salt agar, Eosin methylene blue agar and MacConkey agar at 37 ${ }^{\circ} \mathrm{C}$ for $24-48$ hour. The colonies of each strain were identified according to Quinn et al. (1998)

\subsection{Histopathology}

Small tissue specimens from lungs were fixed in $10 \%$ neutral buffered formalin. After proper fixation, the tissue specimens were trimmed, washed in running tap water, dehydrated in different ascending grades of ethyl alcohol, cleared in xylene and embedded in paraffin. The paraffin embedding blocks were sectioned at $5 \mu \mathrm{m}$ thickness then stained by hematoxylin and eosin stain according to Bancroft et al. (1994).

\section{RESULTS}

\subsection{Bacterial isolation:}

Various types of bacteria were detected in 26 cases out of 159 cases $(16.35 \%)$, and these types were Staphylococcus aureus, Streptococcus pneumoniae, Escherichia coli, Klebsiella pneumoniae, and mixed infection (Staphylococcus aureus and Escherichia coli). These data were summarized in Table (1).

\footnotetext{
* Corresponding author: Eman Mohamed, Pathology Department, Faculty of Veterinary Medicine, Benha University, Egypt
} 


\subsection{Histopathological findings:}

The incidence of different pathological lesions in the examined lungs of sheep and goat were shown in table (2).

Table 1 Typing of various bacterial isolates among the total affected cases of sheep and goat lungs.

\begin{tabular}{|c|c|c|c|}
\hline $\begin{array}{c}\text { Affected } \\
\text { species }\end{array}$ & Bacterial infection & $\begin{array}{c}\text { No. of isolated } \\
\text { bacteria }\end{array}$ & percentage \\
\hline \multirow{4}{*}{ Sheep } & Staphylococcus aureus & 10 & $38.46 \%$ \\
\hline & Streptococcus pneumoniae & 7 & $26.92 \%$ \\
\hline & Escherichia coli & 4 & $15.38 \%$ \\
\hline & Klebsiella pneuтопiae & 1 & $3.84 \%$ \\
\hline \multirow{2}{*}{ Goat } & Escherichia coli & 2 & $7.69 \%$ \\
\hline & $\begin{array}{c}\text { mixed infection } \\
\text { (Staph. aureus } \text { and } E \text {. coli) }\end{array}$ & 2 & $7.69 \%$ \\
\hline
\end{tabular}

Table 2 Incidence of different pathological lesions in the lungs of small ruminant collected between February 2018 and November 2019.

\begin{tabular}{|c|c|c|c|c|c|}
\hline \multirow[t]{2}{*}{ Lesions } & \multirow{2}{*}{$\begin{array}{l}\text { Isolated } \\
\text { bacteria }\end{array}$} & \multicolumn{2}{|c|}{ No. of cases } & \multicolumn{2}{|c|}{ percentage } \\
\hline & & sheep & goat & sheep & goat \\
\hline Emphysema & - & 35 & 2 & $\begin{array}{l}26 . \\
1 \%\end{array}$ & $8 \%$ \\
\hline Atelectasis & - & 7 & 2 & $5.2 \%$ & $8 \%$ \\
\hline $\begin{array}{l}\text { Passive } \\
\text { hyperemia }\end{array}$ & - & 5 & 3 & $3.7 \%$ & $12 \%$ \\
\hline $\begin{array}{l}\text { Pulmonary } \\
\text { edema }\end{array}$ & - & 5 & 3 & $3.7 \%$ & $12 \%$ \\
\hline $\begin{array}{l}\text { Pulmonary } \\
\text { hemorrhage }\end{array}$ & - & 3 & 1 & $2.2 \%$ & $4 \%$ \\
\hline $\begin{array}{l}\text { Bronchitis and } \\
\text { bronchiolitis }\end{array}$ & - & 31 & 3 & $23.1 \%$ & $12 \%$ \\
\hline Suppurative & Staph. aureus & 9 & 1 & $6.7 \%$ & $4 \%$ \\
\hline pneumonia & $\begin{array}{c}\text { Strept. } \\
\text { pneumoniae }\end{array}$ & 7 & - & $5.2 \%$ & - \\
\hline $\begin{array}{l}\text { Fibrinous } \\
\text { pneumonia }\end{array}$ & - & 10 & 2 & $7.5 \%$ & $8 \%$ \\
\hline $\begin{array}{l}\text { Interstitial } \\
\text { pneumonia }\end{array}$ & - & 8 & 2 & $5.9 \%$ & $8 \%$ \\
\hline $\begin{array}{l}\text { Granulomatous } \\
\text { pneumonia }\end{array}$ & $\begin{array}{l}\text { Escherichia } \\
\text { coli }\end{array}$ & 2 & - & $1.5 \%$ & - \\
\hline $\begin{array}{l}\text { Verminous } \\
\text { pneumonia }\end{array}$ & - & - & 5 & - & $20 \%$ \\
\hline $\begin{array}{l}\text { Affection in } \\
\text { pleura (pleural } \\
\text { fibrosis) }\end{array}$ & - & 6 & 1 & $4.5 \%$ & $4 \%$ \\
\hline $\begin{array}{l}\text { Pulmonary } \\
\text { adenomatosis }\end{array}$ & - & 4 & - & $3 \%$ & - \\
\hline Fibrosarcoma & - & 2 & - & $1.5 \%$ & - \\
\hline
\end{tabular}

\subsubsection{Abnormalities of inflation}

3.2.1.1. Emphysema:

Grossly, the emphysematous areas appeared pale in color and plugged above the surrounding lung surface. Microscopically, emphysema was mostly observed in association with bronchitis and different types of pneumonia. The emphysematous pulmonary alveoli were dilated and distended with air. Some alveoli were ruptured, and the interalveolar septa were destroyed with communication of adjacent alveoli forming syncytium.

\subsubsection{Atelectasis:}

Grossly, atelectic areas were dark red in color, slightly depressed under the surrounding tissue, and sharply well demarcated from the adjacent pulmonary tissue. Microscopically, the atelectic pulmonary alveoli were collapsed and appeared as parallel slits. Atelectasis may be seen beside large sized abscess or in between large areas of lung fibrosis.

\subsubsection{Circulatory disturbances}

3.2.2.1. Passive hyperemia:

Grossly, the affected lung showed dark red colored patches all over their surfaces. Microscopically, the interalveolar blood capillaries were severely dilated and engorged with blood. Moreover, the alveolar lumen was packed with transudate which takes purplish to pinkish coloration

3.2.2.2. Pulmonary edema:Pulmonary edema of the noninflammatory type characterized grossly by dark red lungs that were voluminous, heavy, moist in cut surface, with rib imprints on their surfaces. Microscopically, the pulmonary alveoli showed homogenous faint eosinophilic material in their lumenae with focal areas of compensatory alveolar emphysema.

\subsubsection{Pulmonary hemorrhages:}

Macroscopically, the lungs showed dark red patches on the pulmonary surfaces. Microscopically, scattered red blood cells were seen both in the interalveolar and interlobular septa.

\subsubsection{Bronchitis and bronchiolitis}

In acute cases, marked congestion in the mucosa of bronchi and bronchioles was seen, while in the chronic cases, the bronchial lumenae were packed with an abundant amount of mucous exudate and the bronchial walls were thickened.

Microscopically, acute bronchitis and bronchiolitis showed congestion of blood vessels and mononuclear leukocytic cellular infiltrations mainly lymphocyte in the peribronchiolar areas. Chronic cases were characterized microscopically by marked hyperplasia and desquamation of the lining epithelium of bronchioles with the presence of a large amount of exudate in their lumenae, which occasionally was organized and associated with heavy peribranchial leukocytic cellular infiltration (Fig. 1a).

\subsubsection{Pneumonia}

3.2.4.1. Suppurative bronchopneumonia and lung abscess Grossly, the affected lungs were consolidated, dark red in color, and showed the presence of grayish-white, varied sized abscesses in the surface of the pulmonary tissue (Fig. 1b). In cut surfaces; scanty grayish-white pus came out from the bronchial lumenae (Fig. 1c). Microscopically, acute suppurative broncho-pneumonia revealed presence of suppurative exudate formed from the aggregation of dead and live neutrophils mixed with few numbers of mononuclear leukocytic infiltrations in the lumen of bronchioles and the alveoli (Fig. 1d). Meanwhile, abscesses appeared as focal structureless eosinophilic and basophilic substances infiltrated with neutrophil and surrounded by fibrous connective tissue capsule (Fig. 1e).

\subsubsection{Fibrinous Pneumonia:}

Grossly, the affected lungs were hepatized and showed diffuse consolidated dark red areas associated with the thickening of pleura. Microscopically, the lumenae of alveoli, bronchi and bronchioles were filled with eosinophilic fibrinous exudate mixed with leukocytic cellular infiltration especially neutrophils (Fig. 1f). 


\subsubsection{Interstitial Pneumonia:}

Macroscopically, the affected lungs were firm and dry in cut sections and showed focal pale-colored patches distributed all over their surfaces. Microscopically the lungs showed thickening of the interalveolar septa with the presence of macrophages and lymphocytes in the lumenae of alveoli (Fig. 2a).

\subsubsection{Granulomatous Pneumonia:}

Granulomatous Pneumonia was recorded only in lungs of sheep. Grossly, the affected lungs showed multiple palecolored nodules of different sizes scattered all over their surface. Microscopically, the pulmonary granuloma exhibited heavy aggregation of mononuclear leukocytic infiltration around the caseated center and occasionally enclosed with a connective tissue capsule (Fig. 2b).

3.2.4.5. Verminous Pneumonia:

Verminous Pneumonia was observed in lungs of goats. Such type of Pneumonia could not be detected grossly and microscopically it characterized by the presence of crosssection of parasite occluded the bronchial lumen surrounded by large areas of hemorrhages (Fig. 2c). Furthermore, the eggs of this parasite were commonly embedded in-between erythrocytes (Fig. 2d).
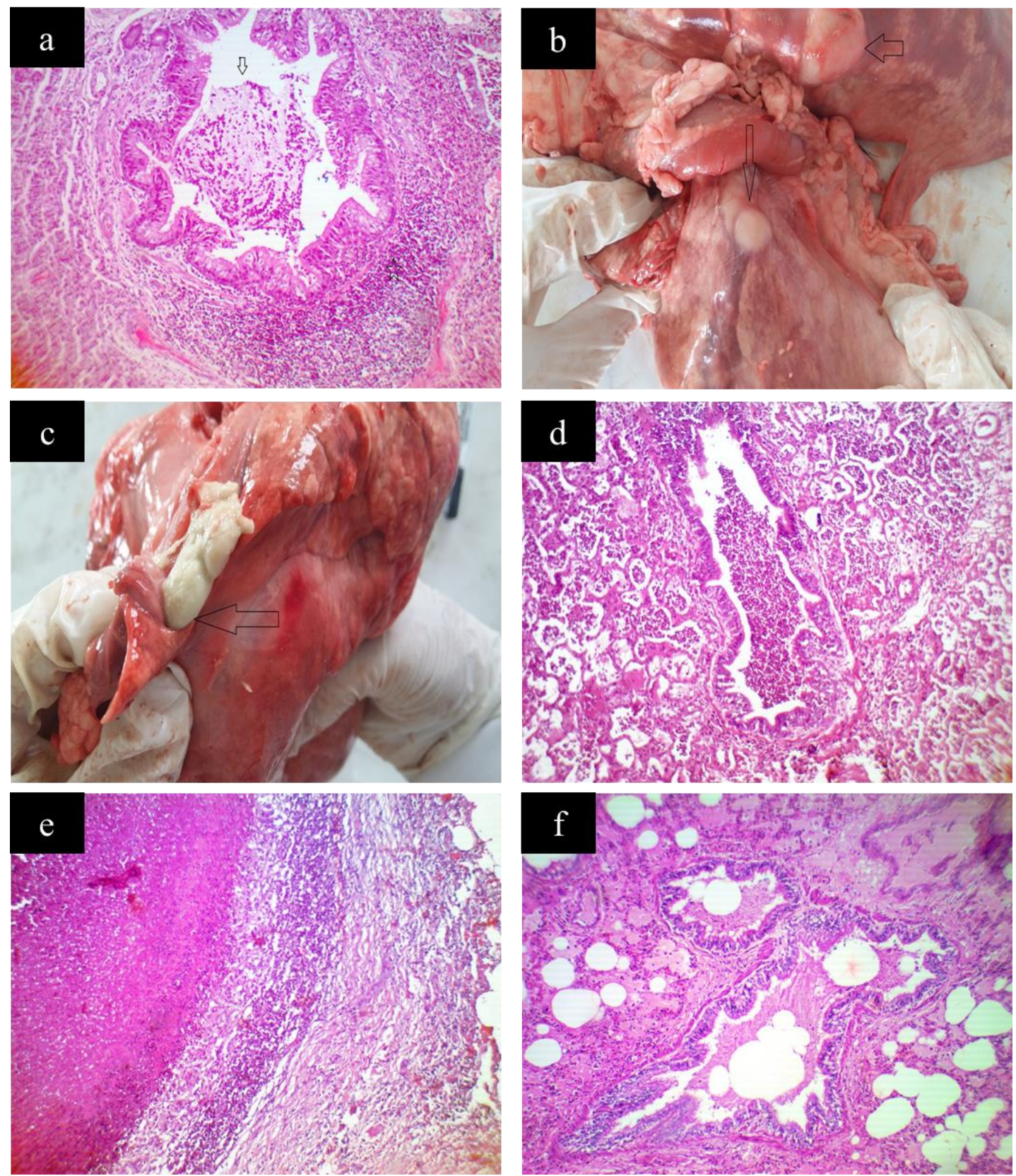

Figure 1 Lung taken from affected animals, showing (a) Marked hyperplasia and desquamation of the lining epithelium of bronchiole with presence of organized exudate in the lumen (arrow) associated with heavy peribronchial leukocytic cellular infiltration (star). (H\&E x200). (b) Grayish white varied sized abscesses in the pulmonary surface (arrow). (c) Scanty grayish white pus came out from the bronchial lumen in cut section (arrow). (d) Aggregation of dead and live neutrophils mixed with few numbers of mononuclear leukocytic infiltrations in the lumen of bronchiole and the alveoli. (H\&E x 100). (e) Old abscesses formed from focal structureless eosinophilic and basophilic substance infiltrated with leukocytes especially neutrophil and surrounded by fibrous connective tissue capsule. (H\&E x100). (f) Fibrinous exudate mixed with leukocytes in the lumenae of alveoli, bronchi and bronchiole. (H\&E x 200) 

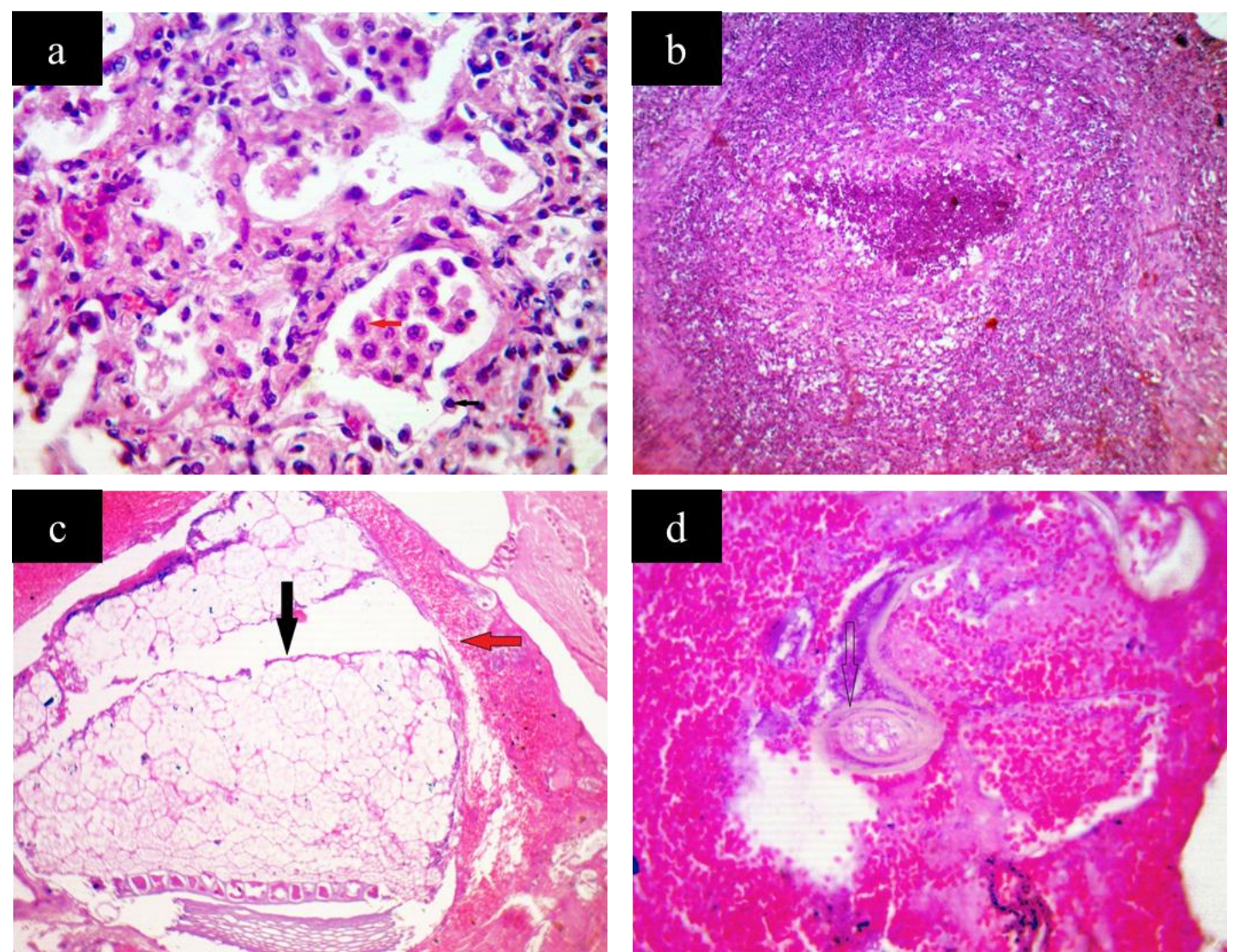

Figure $2 \mathrm{H} \& \mathrm{E}$ stained section of lung, showing (a) Thickening of the interalveolar septa with presence of macrophages (red arrow) and lymphocytes (black arrow) in the lumen of affected alveoli. (x 400). (b) Heavy aggregation of mononuclear leukocytic infiltration around caseated center and enclosed with connective tissue capsule (x 100). (c) Cross sections of the parasite (black arrow) occluded the bronchial lumen surrounded by large areas of hemorrhages (red arrow) (x 100). (d) Eggs of this parasite (arrow) embedded in between erythrocytes. ( $\mathrm{x} 400$ ).

\subsubsection{Affections of pleura (pleural fibrosis):}

Macroscopically, the pleura was thickened, opaque and showed velvety appearance. Microscopically, the affected pleura was thickened due to edema and fibrous connective tissue proliferation accompanied by areas of subpleural emphysema.

3.2.6. Neoplasms:

Pulmonary adenomatosis and fibrosarcoma were recorded in sheep only.

\subsubsection{Pulmonary adenomatosis:}

Grossly, the affected lungs were voluminous, firm in consistency, with the presence of numerous grayish-white variable-sized nodules containing grayish fluid on the cut section (Fig. 3a). Microscopically, the neoplastic pulmonary alveoli were lined by proliferating cuboidal to columnar cells forming papillary projections that extended into the alveolar lumenae with leukocytic cell infiltration mainly lymphocytes in the parabronchial areas (Fig. 3b). The bronchioles showed hyperplasia of the lining epithelial cells formed papillary projections with the presence of inflammatory cells, mainly macrophages, lymphocytes, plasma cells, and giant cells with few neutrophils in their lumenae (Fig. 3c).

\subsubsection{Fibrosarcoma:}

Fibrosarcoma was detected in 2 cases. This secondary neoplasm microscopically was formed from malignant fibroblasts intermixed with collagen fiber in the form of whorls (Fig. 3d). These neoplastic cells showed high degree of pleomorphism and anaplasia which taken various shapes and size of nucleus (Fig. 3e).

\section{DISCUSSION}

The results of bacterial isolation in this study revealed the presence of various types of bacteria isolated from the affected lungs of small ruminants (Table 1). These findings were in partial agreement with Mahmoud et al. (2005) who found that, the main bacterial isolates in sheep and goats were Staphylococcus aureus (12\%), Strept. pneumoniae (4\%), E. coli (8\%), Pseud. aeruginosa (4\%) and Klebsiella pneumoniae $(8 \%)$.

In this study, emphysema and atelectasis were recorded in $34.1 \%$ and $13.2 \%$ of the examined lungs, respectively. These results were in partial agreement with Hashemnia et al. (2019), who found emphysema in $10.36 \%$ and atelectasis in $6.91 \%$ in sheep. The gross and microscopic findings of emphysematous and atelectatic alveoli in our study were similar to those reported by Kumar et al. (2005) and Hashemnia et al. (2019) in sheep.

In the current work, passive hyperemia was detected in $15.7 \%$ and characterized microscopically by congestion and dilatation of the interalveolar blood capillaries. These results were in partial agreement with Hashemnia et al. (2019), who found hyperemia in $7.11 \%$ and characterized microscopically by the presence of a large number of RBCs and siderocytes out of the blood vessels. 
Our results revealed that; pulmonary edema was observed with an incidence of $15.7 \%$. These results were higher than those recorded by Priyadarshi et al. (2013), and Obaid and Khudair (2016), who found edema in $10.90 \%$ and $10 \%$ in sheep, respectively. In our results, the edematous lungs showed homogenous faint eosinophilic material in the lumen of their alveoli. These finding were in a complete agreement with Kumar et al. (2005) and Priyadarshi et al. (2013) in sheep.

In the present study, an incidence of $6.2 \%$ of pulmonary hemorrhage was lower than the previous reports by
Priyadarshi et al. (2013) at $14.55 \%$ in sheep and Rashid et al. (2013) at $20 \%$ in goat.

Bronchitis and bronchiolitis in our study were observed by $44.1 \%$. These results were in partial agreement with Singh et al. (2017), who found bronchitis and bronchiolitis in $2.22 \%$ cases in sheep and goats. Suppurative Pneumonia was observed with an incidence of $15.9 \%$. In contrast to the present investigation, a higher incidence was recorded by Tijjani et al. (2012), who found purulent Pneumonia in 48\%; Yesuf et al. (2012) at $51.22 \%$ and Obaid and Khudair (2016) at $36.6 \%$ in sheep.
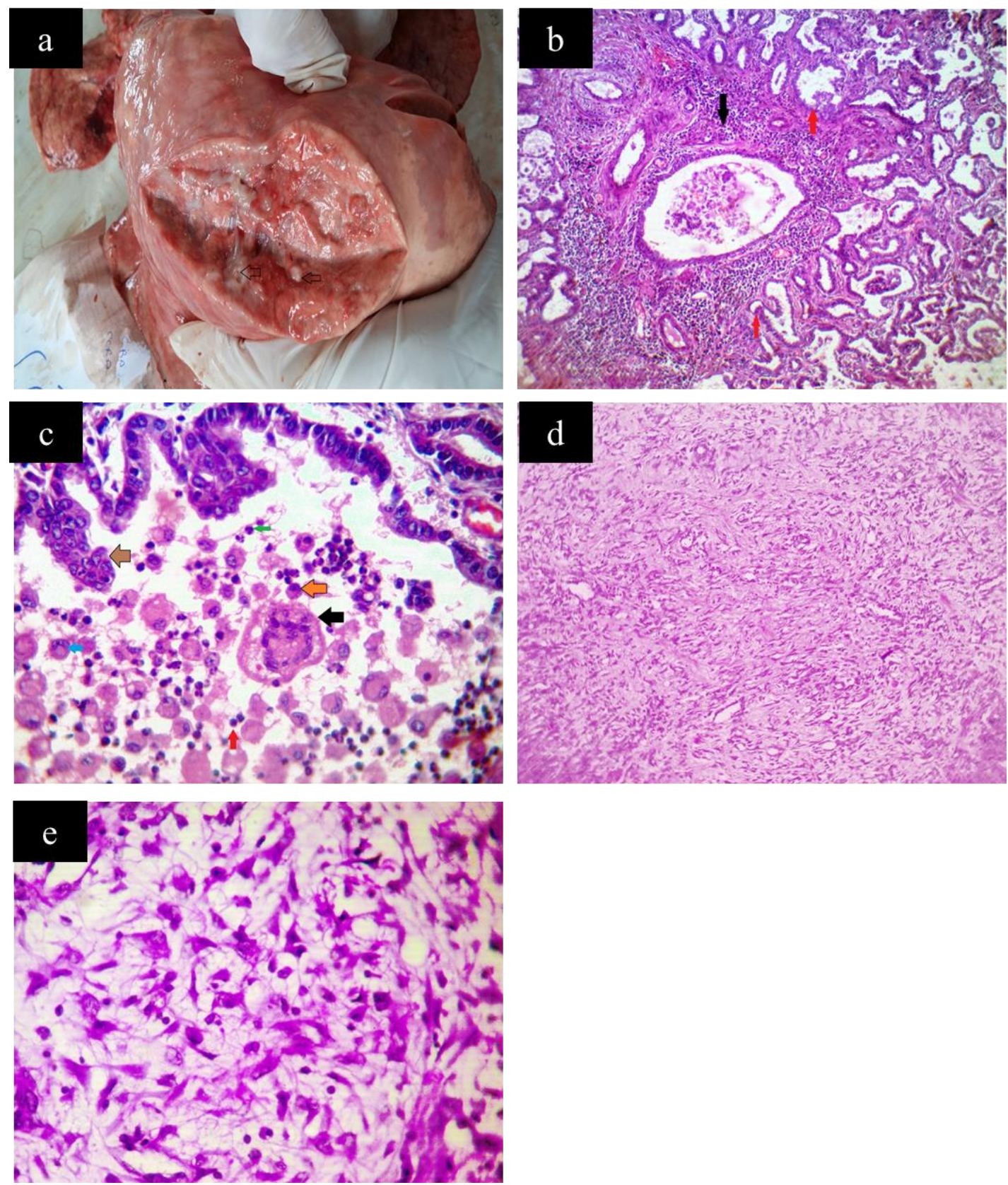

Figure 3 Lung taken from affected animals, showing (a) Numerous grayish white variable sized nodules containing grayish exudate on cut section (arrow). (b) Neoplastic pulmonary alveoli lined by proliferating cuboidal to columnar cells forming papillary projections extended into the alveolar lumen (red arrow) with peribronchial leukocytic cellular infiltration (black arrow). (H\&E x 100). (c) Hyperplasia of the bronchiolar epithelial cells forming papillary projections (brown arrow) with presence of inflammatory cells mainly macrophages (orange arrow), (H\&E x 100). (c) Hyperplasia of the bronchiolar epithelial cells forming papillary projections (brown arrow) with presence of inflammatory cells mainly macrophages (orange arrow),
lymphocytes (red arrow), plasma cells (blue arrow) and giant cell (black arrow) with few neutrophils (green arrow) in their lumen (H\&E x 400). (d) Fibrosarcoma formed from malignant fibroblast intermixed with collagen fiber in the form of whorls. (H\&E x 100). (e) Neoplastic fibroblasts with high degree of pleomorphism and anaplasia which taken various shapes and size of nucleus. ( $x$ 400) 
The isolated bacteria from lungs with suppurative Pneumonia in our study were Staphylococcus aureus, Streptococcus pneumoniae which was also recorded by Yesuf et al. (2012); and in partial agreement with that recorded by Chukwuebuka et al. (2017), who isolates Staph. aureus, klebsiella pneumoniae and E. coli from suppurative cases in sheep lungs. The characteristic features of suppurative Pneumonia and neutrophilic aggregates in this study were in accordance with previous reports by Azizi et al. (2013) in sheep.

Our results revealed granulomatous Pneumonia was seen in examined lungs of sheep with an incidence of $1.5 \%$. Earlier studies by Mira et al. (2014) found a granulomatous lesion in the lungs collected from goats infected with caseous lymphadenitis. Microscopically, the pulmonary granuloma in our work consists of a heavy aggregation of mononuclear leukocytic infiltration around the caseated center and enclosed with a connective tissue capsule. These results completely agreed with Mahdi et al. (2015).

In the current study, verminous Pneumonia was observed in lungs of goat only which represented by $20 \%$ and not detected in the examined lungs of sheep. The lung worms noticed in our work were Metastrongylus and cystocaulus ocreatus. These findings completely disagreed with that mentioned by Ayana and Chanie (2013), who found that lung-worm infection was recorded in slaughtered sheep with an incidence of $57.55 \%$ and named Dictyocaulus filaria, Muellerius capillaris and Protostrongylus rufescens. Pulmonary hydatidosis was another kind of parasitic infection in lungs of sheep as recorded by Priyadarshi et al. (2013), Mahdi et al. (2015) and Singh et al. (2017). In the current work, fibrinous Pneumonia was observed with an incidence of $15.5 \%$, which was lower than those reported by Yesuf et al. (2012) at $39.02 \%$.

The lesions of fibrinous Pneumonia with the presence of fibrin exudate and few neutrophils in the lumen of bronchi, bronchioles, and alveoli observed in the present work are in line with the previous report by Hashemnia et al. (2019). Moreover, previous studies by Azizi et al. (2013), Kumar et al. (2014) and Singh et al. (2017) reported the presence of multifocal areas of necrosis surrounded by a rim of elongated cells, called 'oat cells' or "swirling macrophages" that formed whorl-like structures in and around the alveoli in cases of fibrinous Pneumonia.

In the present work the incidence of interstitial Pneumonia was $13.9 \%$. This incidence was lower than those reported by Tijjani et al. (2012) at 32\%, Yesuf et al. (2012) at 23.61\%, Azizi et al. (2013) at 21.43\% and Obaid and Khudair (2016) at $30 \%$.

In our work, the affected lungs with interstitial Pneumonia exhibited thickening of the interalveolar septa. These results completely agreed with Oruc (2006) and Ugochukwu et al. (2017). Meanwhile, our results were in partial agreement with Azizi et al. (2013), who found multinucleated giant cells with spheroidal to ovoid concentrically lamellar corpora amylacea in the alveolar space in some cases of interstitial Pneumonia.

Our results revealed that, affections of the pleura were observed by an incidence of $8.5 \%$ from examined lungs, which were lower than that recorded by Obaid and Khudair (2016) at $10 \%$ of pneumonic sheep. The thickened, fibrotic pleura in this study are in accordance with earlier studies by Amaravathi et al. (2014)

Pulmonary adenomatosis was represented by $3 \%$ of the examined sheep lungs in our work. These findings were lower than those recorded by Kumar et al. (2005) and Sonawane et al. (2016), who reported incidences of $7.43 \%$ and $8 \%$ respectively. The gross lesions and microscopic proliferative changes in the alveolar and bronchiolar epithelium in the present work were in accordance with the earlier reports by Kumar et al. (2005) and Sonawane et al. (2016). Earlier studies by Sayyari and Mohamadian (2012) reported lesions of Ovine pulmonary adenocarcinoma in goat's lungs that were consistent with our observation in sheep.

\section{CONCULSION}

The incidence of bacterial infection in the lungs of sheep and goat almost represented $16.35 \%$ and Staph. aureus were the most common bacterial pathogens isolated from diseased lungs. Pneumonia is an important lesion in the lungs of small ruminant, and suppurative Pneumonia was the most predominant type. Verminous Pneumonia was detected only in goats and not detected in sheep. Pulmonary adenomatosis were recorded in lungs of sheep but not observed in goat.

\section{CONFLICT OF INTEREST}

The author has no competing interests

\section{REFERENCES}

1. Amaravathi, M. 2014. Pathomorphological studies on spontaneous lung lesions in slaughtered sheep. Thesis, Master of Veterinary Science, Sri Venkateswara Veterinary University Tirupati India.

2. Azizi, S., Korani, F.S. and Oryan, A., 2013. Pneumonia in slaughtered sheep in South-Western Iran: Pathological characteristics and aerobia bacterial aetiology. Veterinary Italiana, 49:109-118.

3. Ayana, K. and Chanie, M., 2013. Study on the prevalence and pathological features of lung worm of sheep inbahir dar Ethiopia. Acta, Parasitologica Globalis. 4: 41-48.

4. Banchroft, D. J., Cook, C. H., Stirling, R. W. and Turner, D. R., 1994. Manual of histological techniques and their diagnostic application. (3rd.ed.) Chuchill Livingstone, Edinburgh. pp: 23-27.

5. Bruere, A.N., West, D. and Ridler, A.L., 2002. Enzootic Pneumonia, In: The sheep: health, disease \& production written for veterinarians and farmers. Palmerston North: Massey University. pp: 100-108.

6. Chukwuebuka, I., Inyang, C., Kenechukwu, C., Philip, W., Olu, S.V, Nwankwo, C., Fionkfu, K. and Ikenna, E., 2017. Pathomorphology and aerobic bacteria associated with Pneumonia in small ruminant slaughtered at the Nsukka Abattoir. Animal Research International. 14: 2644-2651.

7. Goodwin, K.A., Jackson, R., Brown, C., Davies, P.R., Morris, R.S. and Perkins, N.R., 2004. Pneumonic lesions in lambs in New Zealand: patterns of prevalence and effects on production. N. Z .Vet. J. 52: 175-159.

8. Hashemnia, M., Chalechale, A. and Malmir, E., 2019. Pulmonary lesions in slaughtered sheep in Western Iran: gross and histopathological findings. Veterinary Italiana. 55: 47-56.

9. Kumar, R. P., Kumar, R., Somawane, G. G., Paliwal, O. P. and Sharma, A. K., 2005. Studies on pathology of ovine 
pneumonias and experimental Pasteurella multocida infection in rabbits. Indian, Journal of Veterinary Pathology. 29: 29153.

10. Kumar, M.A., Kumar, R., Varshney, K.C., Nair, M.G., Lakkawar, A.W., Sridhar, B.G. and Palanivelu, M., 2014 Pathomorphological studies of lung lesions in sheep. Indian, Journal Veterinary Pathology. 38: 75-81.

11. Lacasta, D., Ferrer, L.M., Ramos, J.J., Gonzalez, J.M. and De Las Herasc, M., 2008. Influence of climatic factors on the development of Pneumonia in lambs. Small Ruminant Research. 80: 28-32.

12. Mahmoud, M.A., Osman, W.A., Goda, A.SA and El Naggar, A.L, 2005. Prevalence of some respiratory diseases among sheep and goats in Shalateen, Halaieb and Abu-Ramad areas. Beni-Suef Veterinary Medical Journal. 15: 196-202.

13. Mahdi, A.A., Al-Naqshabendy, A.A. and Haddel, B.T., 2015. A study of some pathological lesions in the lung of sheep and duhok abattoir. Bas. Journal Veterinary Research. 14: 265277.

14. Mira, C., Fatima, B. K., Fadhela, S., Kada, K. and Yacine, T., 2014. Epidemiological and Histopathological Studies on Caseous Lymphadenitis in Slaughtered Goats in Algeria. Global Veterinaria. 13: 1065-1068.

15. Obaid, A.H and Khudair, Z.W., 2016. The Role of Klebsiella Pneumonia for effect on Pneumonia in the sheep. Kufa Journal for Veterinary Medical Sciences. 7:158-175.

16. Oruc, E. (2006): The pathologic and bacteriologic comparison of pneumonia in lambs. Turkey Journal Veterinary Animal Science. 30: 593-599.

17. Priyadarshi, B. H., Joshi, D. V., Patel, B. J., Raval, S. H. and Patel, H. A., 2013. Pathomorphology of spontaneously occurring pulmonary lesions in sheep (Ovis aries). Ruminant Science. 2: 31-35.

18. Quinn, P.J., Carter, M.E., Markey, B.K. and Carter, G.R., 1998. Clinical veterinary microbiology. ( $2^{\text {nd }}$ Ed), Mosby, London, pp: 137-143, 254-258.
19. Rashid, M.M., Ferdoush, M.J., Dipti, M., Roy, P., Rahman, M.M., Hossain M.I. and Hossain M. M., 2013. Bacteriological and pathological investigation of goat lungs in mymensingh and determination of antibiotic sensitivity. Bangladish Journal Veterinary Medicine. 11: 159-1606.

20. Sayyari, M and Mohamadian, B. 2012. Histopathological study of naturally occurring ovine pulmonary adenocarcinoma in native goat in Khuzestan, Iran. Iranian Journal of Veterinary Research, Shiraz University. 13: 334-338.

21. Singh, R., Kumar, P., Sahoo, M., Bind, R.B, Asok Kumar, M., Das, T., Kumari, S., Kasyap, G., Yadav, J.P., Saminatham, M., Singh,K.P. and Singh, R., 2017. Spontaneously occurring lung lesions in sheep and goats. Indian Journal Veterinary Pathology. 41: 18-24.

22. Sonawane, G. G., Tripathi, B. N., Kumar, R and Kumar, J. 2016. Diagnosis and prevalence of ovine pulmonary adenocarcinoma in lung tissues of naturally infected farm sheep. Veterinary World. 9: 365-370.

23. Tijjani, A.N., Ameh, J.A., Gambo, H.I., Hassan, S.U., Sadiq, M.A and Gulani, I. 2012. studies on the bacterial flora pathologic lesions of caprine pneumonic lungs in Maiduguri North- Eastern Nigeria. African Journal of Microbiological Research. 6: 7417-7422.

24. Ugochukwu, I. C., Aneke, C.I., Ezeasor, C. K., Msheila, W P., Idoko, S. I., Kwabugge, A. Y., Shoyinka, S. V. O., Chineme, C.N., Chah, K.F and Ugochukwu, E. I. 2017. Pathomorphology and aerobic bacteria associated with pneumonia in small ruminants slaughtered at the nsukka abattoir. Animal research, International. 14: 2644 - 2651.

25. Yesuf, M., Mazengia, M. and Mersha, C., 2012. Histopathological and bacterial examination of pneumonic lungs of small ruminants slaughtered at Gondar, Ethiopia. American-Eurasian, Journal of scientific Research. 7: 226 231. 